\title{
METAFISIKA KEJADIAN DALAM PERSPEKTIF TEORI MOSEN
}

\author{
Bertha Wikara
}

\begin{abstract}
Abstrak
Many incidents happen in the universe. They are make humans embittered and try to understand about them. Things about incident were searched in this research : how an incident emerge, actor of all incidents in universe, and formula that represents all incidents in universe and with the using of it. Inductive thinking by using datas which they are not results from an experiment was used as research method. The results of the research are : 1) An incident emerge because a movement, 2) Actor of all incidents in universe is mosen, 3) Formula that represents all incidents in universe is input $=$ output. The formula called incident formula, 4 ) The using of incident formula is for the basic of zero change postulate making, which the postulate's statement is, " there is no change in each incident in universe. Change that happens is not real ", the incident formula is also used for the basic of mosen cycle postulate making, which the postulate's statement is, " each movement of mosen is a cycle ". Point 1 to 3 plus zero change postulate called incident theory.
\end{abstract}

Kata kunci : kejadian, pelaku, rumus, penggunaan.

Di jagad raya terdapat banyak kejadian. Berbagai kejadian terjadi di berbagai wilayah di jagad raya. Kejadian - kejadian tersebut terdiri dari kejadian yang sederhana sampai rumit. Mahkluk hidup ataupun benda mati sama - sama bisa terlibat di dalamnya. Manusia sendiri juga tak luput dari kejadian. Berbagai kejadian terjadi dalam hidup manusia sejak lahir hingga mati.

Banyak usaha yang sudah dilakukan manusia untuk mengungkap rahasia di balik kejadian - kejadian di jagad raya. Berbagai kejadian di jagad raya telah menyebabkan ketertarikan manusia untuk menyelidikinya. Penelitian ini pun dilatarbelakangi hal yang sama.

Bermacam pengetahuan mengenai kejadian di jagad raya telah berhasil didapatkan manusia lewat penelitian. Pengetahuan yang hendak didapatkan melalui penelitian ini adalah pengetahuan mengenai bagaimana sebuah kejadian ada, pelaku semua kejadian di jagad raya, dan rumus yang bisa menggambarkan semua kejadian di jagad raya beserta penggunaan rumus tersebut. 
Tujuan penelitian ini adalah untuk mendapatkan pengetahuan mengenai bagaimana sebuah kejadian ada, pelaku semua kejadian di jagad raya, dan rumus yang bisa menggambarkan semua kejadian di jagad raya beserta penggunaan rumus tersebut. Dengan mendapatkan pengetahuan tersebut, diharapkan semua kejadian di jagad raya dapat dituangkan ke dalam sebuah ketetapan.

Pemikiran induktif dengan memakai data - data bukan hasil eksperimen digunakan sebagai metode penelitian ${ }^{(1)(2)}$.

\section{Hasil dan Pembahasan}

Rumus $\mathrm{E}=\mathrm{m} \cdot \mathrm{c}^{2(3)}$ dan percobaan bom atom membuktikan bahwa materi (massa) bisa berubah menjadi energi. Karena materi bisa berubah menjadi energi, dapat disimpulkan bahwa materi sebenarnya adalah energi.

Karena materi dan energi adalah sama, maka untuk lebih mudahnya disebut saja dengan satu nama, yaitu mosen. Mosen adalah singkatan dari massa dan energi (masen), dengan penggantian huruf "a" menjadi huruf "o".

Jagad raya hanya terdiri dari dua hal yaitu materi dan energi ${ }^{(4)}$. Dengan kata lain jagad raya hanya terdiri dari mosen. Berdasarkan hal itu, dapat disimpulkan bahwa sesuatu yang terkecil (tidak dapat dibagi lagi) di jagad raya adalah mosen, dan sekaligus sesuatu terbesar di jagad raya pun adalah mosen.

Untuk menjelaskan lebih jauh tentang mosen, maka perlu dibahas perbandingan antara materi dan energi. Tadi sudah dijelaskan bahwa materi dan energi adalah sesuatu yang sama, dengan kata lain materi adalah energi. Oleh sebab itu tidak masuk akal bila dikatakan bahwa energi tidak mempunyai massa, sedang materi mempunyai massa. Misalnya, sebuah batu adalah sebuah materi karena batu mempunyai massa. Karena materi adalah energi, maka juga bisa dikatakan bahwa batu adalah sebuah energi. Oleh sebab itu tidak mungkin sesuatu yang mempunyai massa (batu) adalah sesuatu yang tidak mempunyai massa (energi). Maka jelas bahwa energi mempunyai massa.

Massa energi lebih ringan dibanding massa dari materi apapun. Ini terbukti dengan kenyataan bahwa selama ini energi tidak dimasukkan ke dalam golongan materi karena energi dianggap tidak memiliki massa. Karena energi memiliki massa 
lebih ringan dibanding materi, tepat bila dikatakan bahwa unit terkecil (tak dapat dibagi lagi) dari energi adalah massa paling ringan di jagad raya. Materi maupun energi adalah mosen, oleh sebab itu tepat bila unit terkecil dari energi dinamakan biji mosen (untuk memudahkan penggambarannya disebut biji). Jadi biji mosen tak lain adalah biji energi.

Karena jagad raya hanya terdiri dari materi dan energi, atau dengan kata lain jagad raya hanya terdiri dari mosen, maka bisa dikatakan bahwa jagad raya terbuat dari sekumpulan debu. Sekumpulan debu tersebut tak lain adalah biji - biji mosen.

Berdasarkan nalar dapat dikatakan bahwa sebuah kejadian ada karena gerakan. Jika tak ada sesuatu yang bergerak, maka tak ada kejadian. Jagad raya hanya terdiri dari mosen, oleh sebab itu bila mosen tidak bergerak sama sekali, maka tak ada kejadian apapun di jagad raya. Dengan kata lain, bila mosen bergerak maka ada kejadian, dan bila mosen diam maka tak ada kejadian. Jadi setiap kejadian di jagad raya adalah akibat gerakan mosen. Jadi, pelaku semua kejadian di jagad raya adalah mosen.Karena ada gerakan berarti ada kejadian (kejadian adalah gerakan), maka harus dicari rumus gerakan untuk bisa menghasilkan rumus kejadian. Oleh sebab itu dilakukan penyelidikan tentang gerakan dan perumusannya. Gerakan ada karena sesuatu bergerak. Untuk hal ini (untuk yang bersifat teoritis) sesuatu tersebut adalah sesuatu dalam makna luas. Sesuatu tersebut boleh apa saja, tidak harus mosen.

Sesuatu yang bergerak adalah sesuatu yang mengalir karena gerakan berarti aliran (arus). Untuk memindahkan aliran ini ke dalam bentuk persamaan, maka dilakukan substitusi. Seandainya aliran ini dinamakan aliran A, lalu dilakukan substitusi dengan memakai 2 aliran, yaitu aliran B dan C, maka bagannya adalah sebagai berikut :

Aliran A

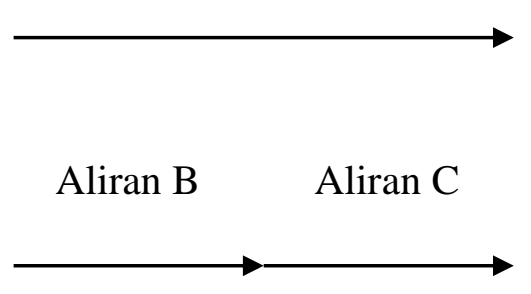


Aliran A = Aliran B + Aliran C

Dapat dilihat bahwa aliran B sama dengan aliran C, sehingga persamaannya :

(Untuk membuat sebuah persamaan yang baik dan benar maka perbandingannya dibuat adil, aliran B sama dengan aliran C. Sedang alasan hanya dibuat 2 aliran, bukan 3 aliran dan seterusnya, adalah untuk penyederhanaan karena dibuat berapa aliran pun akan sama saja, hanya lebih kompleks).

Oleh karena kedua aliran ini bersambung, dan untuk lebih memudahkan pengertian mengenai hal ini, maka rumusnya menjadi :

$$
\text { Input }=\text { Output }
$$

Definisi input maupun output adalah aliran sesuatu (gerakan sesuatu). Sesuatu yang bergerak (mengalir) ini bebas, bisa apa saja. Misal, ini hanya sekedar contoh, sesuatu yang mengalir adalah cinta (cinta bisa menjadi sesuatu yang bergerak (karena digerakkan), dan tentu saja ini adalah sesuatu yang agak bersifat abstrak). Maka persamaannya menjadi :

$$
\text { aliran cinta }=\text { aliran cinta }
$$

Rumus input $=$ output dinamakan saja rumus kejadian. Dinamakan demikian karena rumus ini adalah rumus yang mewakili/menggambarkan kejadian (ingat, ini rumus gerakan, dan kejadian adalah gerakan).

Perlu diingat bahwa pembuatan rumus kejadian adalah dengan pembagian sebuah aliran (gerakan) sesuatu menjadi 2 bagian, yang mana aliran pertama disebut input, dan aliran kedua disebut output. Maka dari itu jelas bahwa sebuah aliran (kejadian) yang digambarkan oleh rumus kejadian adalah sebuah aliran yang sudah ada input dan outputnya (sebuah aliran yang dibagi 2 seperti yang dikatakan tadi), bukan menggambarkan aliran pertama (input) lalu outputnya menyusul muncul. 
Hal yang tidak absolut seperti posisi diabaikan karena tidak benar - benar ada. Jadi, perubahan posisi pada kejadian tidak diperhatikan disini.

Berikut ini dikemukakan penggunaan rumus kejadian untuk pembuatan postulat - postulat tentang jagad raya. Seperti telah dikatakan bahwa rumus kejadian adalah :

$$
\text { Input }=\text { Output }
$$

Dari rumus tersebut dapat dilihat bahwa tidak ada perubahan apapun yang terjadi. Awal sama saja dengan akhir (ingat, perubahan posisi atau ruang tak diperhitungkan karena bukan hal yang absolut). Karena rumus di atas dapat dipakai untuk semua kejadian di jagad raya, berarti dalam setiap kejadian di jagad raya tidak ada perubahan apapun yang terjadi. Perubahan yang terjadi hanya bersifat semu. Dari uraian ini dapat dikemukakan suatu postulat yang berbunyi :

"Tak ada perubahan apapun dalam tiap kejadian. Perubahan yang terjadi sifatnya semu".

Postulat ini dinamakan saja postulat perubahan nol. Ini adalah postulat tentang jagad raya yang bisa dihasilkan dari rumus kejadian.

Sebelumnya telah disebutkan bahwa jagad raya hanya terdiri dari mosen. Karena itu jika mosen tak bergerak, maka tak ada kejadian. Atas dasar ini sepantasnyalah bila sesuatu yang bergerak/mengalir dalam rumus kejadian adalah mosen. Bila sesuatu yang bergerak adalah mosen, maka hasil awal juga sama saja dengan hasil akhir. Itu menunjukkan bahwa tak ada perubahan apapun yang terjadi. Itu sama saja dengan mosen bergerak, tetapi seolah tak pernah bergerak (bergerak, namun awal sama saja dengan akhir). Ini berarti mosen bergerak dalam sebuah siklus. Atas dasar inilah, maka dapat dikemukakan suatu postulat yang berbunyi :

"Tiap gerak mosen adalah sebuah siklus"

Postulat ini disebut saja postulat siklus mosen. Sekali lagi sebuah postulat tentang jagad raya dapat dibuat dengan memakai rumus kejadian.

Dari semua uraian sebelumnya jelas bahwa rumus kejadian serta pembuatannya termasuk dalam bidang matematika. Artinya, rumus tersebut adalah sebuah perhitungan matematika atau dengan kata lain sifatnya teoritis. Sedang jika 
input dan output terisi aliran mosen, berarti sudah terjun ke bidang fisika. Dalam hal ini sifatnya adalah praktek.

\section{Kesimpulan dan Saran}

1. Sebuah kejadian ada karena gerakan.

2. Pelaku dari semua kejadian di jagad raya adalah mosen.

3. Rumus yang menggambarkan semua kejadian di jagad raya adalah rumus kejadian, yang mana rumusnya adalah input $=$ output.

4. Postulat perubahan nol dan postulat siklus mosen adalah hasil penggunaan dari rumus kejadian. Postulat perubahan nol berbunyi, " tak ada perubahan apapun dalam tiap kejadian. Perubahan yang terjadi sifatnya semu ". Sedang postulat siklus mosen berbunyi, " tiap gerak mosen adalah sebuah siklus ".

Butir satu sampai 3 ditambah postulat perubahan nol disebut saja teori kejadian. Teori kejadian tersebut adalah hasil dari penelitian yang tercantum dalam jurnal ini.

1. Perlu diadakan penelitian lanjutan untuk mengetahui lebih banyak tentang kejadian - kejadian di jagad raya.

2. Perlu dipikirkan kemungkinan penerapan rumus kejadian secara lebih luas di berbagai disiplin ilmu.

\section{Daftar Pustaka}

Azwar, S. 2001. Metode Penelitian. Pustaka Pelajar. Yogyakarta.

Beerling, dkk. 2003. Pengantar Filsafat Ilmu. (Diterjemahkan oleh S. Soemargono). PT. Tiara Wacana Yogya. Yogyakarta.

Tipler, A. P. 2001. Fisika. (Diterjemahkan oleh B. Soegijono). Penerbit Erlangga. Jakarta.

Jasin, M. 1987. Ilmu Alamiah Dasar. PT. Bina Ilmu. Surabaya. 